\title{
Engaging Students in the Community as Part of Classroom Learning and for Future Benefits
}

\author{
Angela M. Thompson \\ St. Francis Xavier University
}

This paper shares the survey results of students' perceptions of the benefits of their experiences with service learning. The service learning experiences were related to children and their physical growth and development and/or to children and their health education. An open-ended questionnaire was sent to 376 graduated students (representing 11 courses over six years) to gather their thoughts regarding the benefits of their service learning experiences several years after completion. Responses were overwhelmingly positive with the most prevalent themes relevant to educational and career goals: "confirmation of future goals," "practical skill development," and "enhance my resume andlor application to a particular field of study/occupation." Given these findings, service learning should be included in post-secondary education not only for the practical experiences that link theory with reality, but also for the potential benefits to students' future career and education.

\section{Introduction}

$\mathrm{I}_{\mathrm{t}}^{\mathrm{n}}$ $\mathrm{n}$ this paper, service learning is defined as volunteer work in response to community need combined with a reflective assignment. In this regard, service learning provides students with an opportunity to test "theory" against "reality" (Barrow, Hofrenning, \& Parkhurst, 2005; Bishop \& Driver, 2007; Dicklitch, 2003). Students' service learning catalyzes their academic and self-development and promotes social responsibility through links between town and gown (Joseph, Stone, Grantham, Harmancioglu, \& Ibrahim, 2007). Another potential benefit of service learning is enhanced short- and long-term academic performance (Strage, 2004). Empirical evidence on short-term academic performance impact is mixed (Matthews-Gardner, Fitzgerald, \& Gitelson, 2005) and inconclusive (Eyler, 2002). It may not be realistic to expect a one-term experience - even with 15-20 hours of service and a reflective course-based 
assignment - to lead to dramatic changes in a student's approach to learning with a resultant impact on academic achievement, or to his/her attitudes and values towards others or the community (MatthewsGardner et al., 2005).

Self-efficacy, interpersonal, communication, and professional skills, and reduced stereotyping and enhanced social responsibility are often considered benefits of service learning (Hunt, 2007; Reising, Allen, \& Hall, 2006). Another factor is the exploration of potential careers (Blieszner \& Artale, 2001). Following their service learning, nursing students saw their profession differently, developed empathy for individuals they worked with, and re-examined their assumptions, perceptions, and stereotypes. This experience and reaction to it reflects the need for service learning to prepare students for the 'real world.' Students in fields that do not lead to a particular career also benefit in that it attunes them to the community's needs (Kronick, 2007) and puts a face on the individuals who live within.

Although some research indicates graduates who participated in service learning were more likely to continue to provide service to their communities (Fenzel \& Peyrot, 2005), little research exists on the long-term benefits (Strage, 2004), and in particular in regard to career development. Thus, the purpose of this study was to explore the influences of students' service learning experiences several years after completion. The service learning the students experienced was with children and was part of their classes pertaining to the physical growth and development of children and/or their health education.

\section{Method}

\section{Design and participants}

Data were obtained from a self-report questionnaire mailed to the graduates' last known address. Invitations to participate along with a questionnaire regarding their service learning experiences were sent with stamped return envelopes to all 376 graduates who took either or both Health Education or Child Growth and Development from six academic years representing 11 course offerings. Research ethics approval was received and return of the questionnaire implied consent.

\section{Measures}

Graduates were asked demographic information (sex, age, graduation year) and open-ended questions (Table 1) about their service learning experiences regarding the main benefit, the role in preparation for other academic programs and career selection, and advice for future students.

\section{TABLE 1 \\ Open-ended Questions}

1. Why did you choose to participate in service learning?

2. What were the main benefits from participating in service learning?

3. (If applicable) In what ways did your service learning experience(s) help you to further your education?

4. (If applicable) In what ways did your service learning experience(s) help you in fulfilling your career choice?

5. What would you say to a current student who was offered the option of participating in service learning?

\section{Data analysis}

Descriptive statistics were calculated using SPSS 15.0 (Chicago, IL). Thematic analyses were used for the open-ended responses with key words and phrases identified. Similar to Anderson (2003), the results were additive, rather than reductive with layers accumulating for the interpretation.

\section{Results}

The data presented in Table 2 describes the participants in this study. Each open-ended question was analyzed separately with themes presented hierarchically. For the question, Why did you choose to participate in service learning?, six themes were given: 1) to give back to the community; 2) to experience 
working with children; 3) "beef up" my resume/ application; 4) it was required; 5) to have fun/be physically active; and 6) to develop communication and/or leadership skills. The majority of graduates commented on "giving back" or getting involved with the community. The second most prevalent comment was "working with children" with fewer graduates reporting: "helped to prepare me for education/teaching" and "discovering that teaching/ working with children was not for me."

For What were the main benefits from participating in service learning?, six themes were noted: 1) skill and/or confidence development; 2) experience working with children; 3) community building; 4) putting theory into practice/better understanding of course content; 5) working with classmates/peers; and 6) confirmed/refuted/assisted with career selection and/or built resume. The first three themes were relatively equally reported. Graduates noted several skills that were enhanced including: collaboration, communication, problem solving, time management, organization, and leadership. The theme working with children included interacting, speaking, playing, and becoming comfortable with children. Community building included giving back to the community, feeling a part of the local community, helping a child learn, and promoting physical activity.

For In what ways did your service learning experience (s) help you to further your education?, four themes emerged: 1) directly on my application, in the interview, and in the program; 2) directed my career choice; 3) facilitated learning of class material; and 4) skill development. Most graduates commented on their experience as directly related to their future education (i.e., getting into program of choice) in the application process (because it enhanced their resume), during their interview (because of practical examples) and while in the program (ideas and skills to

TABLE 2

Sample Description

Total number of respondents: $64(17.0 \%)$

Female $=45(70.4 \%)$

Age $=24.3 \pm 2.0 \mathrm{yrs}$ (range $=22-30 \mathrm{yrs}$ )

Employed full time $=28(43.8 \%)$

Studying full time $=27(42.2 \%)$

Service learning in both class $=42(65.6 \%)$

Service learning in a physical activity setting $=48(74.2 \%)$

Service learning in an academic setting $=17(17.5 \%)$

Year of graduation

\begin{tabular}{|l|c|c|c|c|c|c|}
\hline Year & 2002 & 2003 & 2004 & 2005 & 2006 & 2007 \\
\hdashline Number & 3 & 6 & 11 & 5 & 13 & 25 \\
\hline Percent & 4.7 & 9.4 & 17.2 & 7.8 & 20.3 & 39.1 \\
\hline
\end{tabular}

\section{Further academic pursuits $=53(82.8 \%)$}

\begin{tabular}{|l|c|c|c|c|}
\hline Field & Education & $\begin{array}{c}\text { Physiotherapy } \\
\text { Occupational } \\
\text { Therapy }\end{array}$ & $\begin{array}{c}\text { Medicine } \\
\text { Chiropractic } \\
\text { Dentistry }\end{array}$ & $\begin{array}{c}\text { Post- } \\
\text { Graduate } \\
\text { Studies }\end{array}$ \\
\hline Number & 28 & 11 & 5 & 7 \\
\hline Percent & 52.8 & 20.8 & 9.4 & 13.2 \\
\hline
\end{tabular}


teach). The second most frequent response indicated that the service learning experiences directed their career or education choices - either confirming or refuting what they wanted to do. Fewer graduates responded about the experiences helping them to learn or "putting theory into practice" and/or increased knowledge of children. The least frequent response was personal skill development.

Three themes were found for the question, In what ways did your service learning experience(s) help you in fulfilling your career choice? The most prevalent comment made was that the interest in a particular occupation (i.e., teaching) and/or thoughts to not work directly with children were confirmed. The second most frequent responses related to skill development that graduates noted was "so that I can be better at what I do" or "use the skills learned and put them into practice in my current work." The least frequently reported theme related to assistance with acceptance to the students' program of choice. Finally, approximately $10-15 \%$ did not provide a reply or indicated "no, not really."

For the last question, What would you say to a current student offered the option of participating in service learning?, six themes were noted: 1) do it!; 2) an excellent experience - feels good to be involved, to give back, to make a difference; 3) an opportunity to learn more about yourself and/or to develop personal and professional skills; 4) an opportunity to find out if your career is for you, to find a career; 5) a unique offering that should not be missed!; and 6) a fun experience, a stress reliever, something different than hitting the books! All graduates that responded to this survey recommended the service learning experience. "Do it" was used several times with or without further explanation. The reason most frequently listed to "do it" related to community building - giving back to the community/being involved in the community/helping children/promoting physical activity. Several graduates advised current students to learn as much as they can from the experience - personally and professionally; that again, it was a career enhancer or deciding factor. Service learning was also frequently described as a valuable experience, a unique opportunity, and a stress reliever that added fun to their class responsibilities. It is interesting to note that of all the open-ended questions, this one generated the greatest variety in responses.

\section{Discussion}

Several years after completion of their service learning experiences, graduates were overall overwhelmingly positive in their feedback regarding working with children related to their physical growth and development and/or to their health education. However, perhaps only those with positive experiences completed the questionnaire and the questions asked were biased towards obtaining perceptions of the benefits of service learning experiences and did not ask about potential negative aspects.

The most common thread identified by the graduates was a desire to give back to the community and to do something meaningful as noted below.

\section{The experience is very valuable - feels good to volunteer in the community and at the same time get experience in your field.}

This finding is similar to others. Specifically, service learning (also 1-6 years after completion) positively influenced students' "attitudes towards social and personal responsibility, the importance of political participation, and continued service involvement" (Fenzel \& Peyrot, 2005, p. 29). Graduates in this study described the main benefits of their experiences as developing skills to work with children, with this theme found in the responses to each question. Graduates specifically identified improved ability to communicate with children, more effective working relationships with their peers, and enhanced leadership skills. This collection of skills was believed to assist in furthering their education and fulfilling their career aspirations. Other researchers also noted that students recognize the general skills developed (Gandy, Pierce, \& Brooke-Smith, 2009; Madsen \& Turnbull, 2006) and the importance of becoming sensitive to differences in cultures - something that could not be learned from a textbook or lecture (Meaney, Bohler, Kopf, Hernandez, \& Scott, 2008).

In regards to furthering their education and/ 
or fulfilling their career, students mostly perceived a direct benefit. In fact, similar to research by McClam, Diambra, Burton, Fuss, \& Fudge (2008), the graduates indicated their experiences confirmed or refuted their anticipated career paths.

\section{Service learning reinforced how much I wanted to work with children and teach. Fit for Life [physical activity program] was an amazing experience and made me want to be a P.E. teacher even more.}

Further, the graduates developed skills that helped to prepare them to become teachers. This supports the work of Joseph et al. (2007) where the students indicated that they believed their experience "prepar[ed] them for the job market" (p. 331). Interestingly, each response set had a theme related to career development, and whether it was enhancing application or confirming desired career choice, it was viewed as a reason for choosing to participate in service learning, as a main benefit from participating, as an experience that helped to further education and fulfilling career choice, and as part of the reasons why future students should participate in service learning.

The advice to future students given the opportunity to participate in service learning was overwhelmingly positive. Future students were strongly encouraged to take the opportunity and run with it. It was clear how much these graduates valued and benefitted from their personal service learning experience(s):

I would encourage them 100\%. It is a once in a lifetime opportunity where you not only learn about children and their development patterns and behaviours, but you learn a lot about yourself as an individual and the experience allows you to grow and develop as an individual.

Many students also perceived an academic benefit from their participation in service learning in that they said it helped to learn and remember the materials. This is similar to the findings of McClam et al. (2008) where "one student wrote [in his/her journal], I learned more...by emersion into the field than I could have learned sitting in a classroom for four years" (p. 242). Academic benefits are most often viewed as short-term benefits, i.e., for the particular class the experience was in and in the rest of the participants' program.

\section{It helped me to see first hand what I learned in the classroom, it helped me to relate the information to real life situations.}

In conclusion, similar to Village (2006) who noted "the inclusion of service learning opportunities in physical therapist education is one way in which to engage students in these professional activities and to better prepare them to meet the expanding expectations of the communities that they serve" ( $p$. 16), the results of this study indicate that students perceived they were better prepared for their careers as a result of their service learning. Given the overwhelmingly positive benefits students' perceived from their experiences, service learning should be offered to enhance the students' academic experience and to provide practical opportunities that assist with career choice and develop future leaders. As one respondent noted:

Take this opportunity and run with
it! Not every university offers such
a program that allows students to
volunteer in many different places.
No matter where you pick to be
placed, you are able to learn so much
by other volunteers, the workers, or
by the clients. Take every situation as
an opportunity to learn and grow as a
student and person. You may even be
given the chance to choose a placement
that may be a career choice, find out
if it is right for you. Service learning
is one of the best things at [university
name] because it helps the community
and the students.

Take this opportunity and run with it! Not every university offers such a program that allows students to volunteer in many different places. No matter where you pick to be placed, you are able to learn so much by other volunteers, the workers, or by the clients. Take every situation as an opportunity to learn and grow as a student and person. You may even be given the chance to choose a placement that may be a career choice, find out if it is right for you. Service learning is one of the best things at [university and the students. 


\section{References}

Anderson, D.D. (2003). Students and service staff learning and researching together on a college campus. Michigan Journal of Community Service Learning, Spring, 47-58.

Barrow, L., Hofrenning, D., \& Parkhurst, J. (2005). Track three: Experiential learning. PSOnline, 418-419. Retrieved from www.apsanet.org

Bishop, J. \& Driver, S. (2007). Implementing servicelearning in undergraduate adapted physical education. Journal of Physical Education, Recreation, and Dance, 78(8), 15-19.

Blieszner, R. \& Artale, L.M. (2001). Benefits of intergenerational service-learning to human services majors. Educational Gerontology, 27, 71-87.

Dicklitch, S. (2003). Real service = real learning: Making political science relevant through service learning. PSOnline, 773-776. Retrieved from www.apsanet.org

Eyler, J. (2002). Reflection: Linking service and learning - Linking students and communities. Journal of Social Issues, 58(3), 517-534.

Fenzel, L.M. \& Peyrot, M. (2005). Comparing college community participation and future service behaviors and attitudes. Michigan Journal of Community Service Learning, Fall, 22-31.

Grandy, S. K., Pierce, J., \& Brooke-Smith, A. (2009). Collaboration with community partners: engaging teacher candidates. The Social Studies, Jan/Feb, 41-45.

Hunt, R. (2007). Service-learning: An eye-opening experience that provokes emotion and challenges stereotypes. Journal of Nursing Education, 46(6), 277-281.
Joseph, M., Stone, G.W., Grantham, K., Harmancioglu, N., \& Ibrahim, E. (2007). An exploratory study on the value of service learning projects and their impact on community service involvement and critical thinking. Quality Assurance in Education, 15(3), 318-333.

Kronick, R.F. (2007). Service learning and the university student. College Student Journal, 41(2), 296.

Madsen, S.R. \& Turnball, O. (2006). Academic service learning experiences of compensation and benefit course students. Journal of Management Education, 30(5), 724-742.

Matthews-Gardner, L., Fitzgerald, K., \& Gitelson, A.R. (2005). Track six: Service learning. PSOnline, 423-424. Retrieved from www. apsanet.org

McClam, T., Diambra, J.F. Burton, B., Fuss, A., \& Fudge D.L. (2008). An analysis of a servicelearning project: students' expectations, concerns, and reflections. Journal of Experiential Education, 30(3), 236-249.

Meaney, K.S. Bohler, H.R., Kopf, K., Hernandez, L., \& Scott, L.S. (2008). Service-learning and pre-service educators' cultural competence for teaching: an exploratory study. Journal of Experiential Education, 31(2), 189-208.

Reising, D.L., Allen, P.N., \& Hall, S.G. (2006). Student and community outcomes in service learning: Part 1 - Student perceptions. Journal of Nursing Education, 45(12), 512515.

Strage, A. (2004). Long-term academic benefits of service-learning: When and where do they manifest themselves? College Student Journal, 38(2), 257-261. 
Village, D. (2006). Qualities of effective service learning in physical therapist education. Journal of Physical Therapy Education, 20(3), 8-17.

\section{Acknowledgements}

Thank you to the students in Human Kinetics who participated in service learning and willingly shared their perspectives. Thank you also to the St. Francis Xavier University staff dedicated to service learning and in particular Marla Gaudet, for creating and facilitating community connections. This research was financially supported by the StFX Service Learning Faculty Development and Research Support Fund.

\section{Biography}

Angela M. Thompson is 3M Teaching Fellow (2010) and an Associate Professor in the Department of Human Kinetics at St. Francis Xavier University. She is an advocate for service learning, incorporating it in her Child Growth and Development and Health Education classes, and actively conducts research in the field. 